\title{
Posthumanism and the Ends of Education
}

\author{
Stefan Herbrechter (Heidelberg University)
}

Let's start with the obvious. ${ }^{1}$ If you look at the word "post-human-ism", it contains three elements: there's the human in the middle, there's the "post-" in front of it, and there's an "-ism" at the end. An "-ism" usually tells you it's a discourse, like humanism, too, is a discourse, in the sense that everything that is being said about the human, or to make sense of the human, is part of that discourse. And posthumanism would therefore be a discourse about what it means to no longer be human, at least in a humanist sense. That's the minimal definition of any posthumanism I'd suggest; it basically means we're no longer happy with humanist ways of defining what it means to be human.

There are of course many humanisms that are being "posted" by a number of posthumanisms. There's Renaissance or early modern humanism which is based on $14^{\text {th }}$ and $15^{\text {th }}$-century developments that may be summarised by a move towards an anthropocentric world picture. It also implies the move towards modern science in which it becomes legitimate to produce knowledge about who we are, what you know, and what the world and reality are, without looking towards religion for ultimate answers. One could say that anthropocentric humanism is the beginning of a certain species selfcenteredness of the human. So, that's one way to begin the history of humanism: it is that historical development, or worldview which connects with the shift from the (premodern) Middle Ages to the (early modern) Renaissance, i.e. the "long version" of modernity. On its own, however, this explanation would ignore the fact that the Renaissance itself is the return to Greek and Roman Antiquity as a belatedly rediscovered source of a first anthropology, based on the notions of the human as a speaking animal endowed with reason (zoon logon echon, or animal rationale). The rule of reason through the proper use of language (hence the centrality of grammar and rhetoric) is the basis for Enlightenment humanism and the beginning of modern ideas of education.

Then there's also a more narrowly defined humanism that is connected with developments within science itself, and with a move away from the last remainders of religion, in the $19^{\text {th }}$ century, with sciences like evolutionary biology, astrophysics, neuroscience and informatics gradually becoming the only legitimate knowledge formations to explain who and what humans are. Modern science itself contains a fundamental ambiguity as to humanism, however. On the one hand, it allows humans, and humans alone, to harness the power and resources of knowledge, which consolidates the idea of human exceptionalism. On the other hand, scientific reality also works, and maybe even works best, so to speak, without humans, especially with respect to their self-understanding as individual subjects. Today, in the 20th and $21^{\text {st }}$ century, after the experience of two world wars, the holocaust and innumerable other genocides providing ample evidence of inhumanity, a form of humanism survives that is very much focused on human rights and on the preservation of human "sanctity" in the face of violence, vulnerability, inequality and various extinction threats. Humanism is thus itself a very contradictory discourse. It works with a notion of humanness based on exclusivity - humans are not really (or at least not only) animals; they have bodies that aren't (pure) machines; they are material but also spiritual; they constitute a species with a "human nature", made up of radically unique individuals, and so on. Posthumanism or the number of posthumanist reactions to this contradictory human condition and its attempts at selfdefinition - seizes upon the conceptual problems within humanism and radicalises, deconstructs or sometimes also represses them.

Posthumanists see themselves as successors to and critical inheritors of this humanist "mess", one could say, but the prefix "post-" is a very funny animal. It's not just a straightforward attempt to move on, to oppose or to overcome. A post can't achieve any of these moves, instead the prefix "post-" is more like a signal that there is (for want of a better word) an ongoing deconstruction of that which is being posted. It's a kind of conceptual parasite that inhabits humanism itself and tries to bring it to address its own contradictions. And so posthumanism is not really defined against anything else. It incorporates humanisms and tries to push them to some kind of edge where humans would have to put their cards on the table and address their own exclusions, their own contradictions and their own actions. The idea of a critical and "deconstructive" posthumanism is to maybe not so much overcome humanism, but actually to break it up, for something else to be able to take place, in order to, eventually, get out of humanism - conscious, however, that this is not an easy thing to do. A well-established worldview like humanism is not going to be superseded or abolished within a few days; you have to work with the cracks and the contradictions that are within this discourse, and try and break these open for something else, something entirely different to start happening, namely a completely new understanding of what it means to be human not based on the traditional exclusions. This means that the old "others" against which we have defined ourselves are not simply going to disappear. The 
machine has been with us and is taking on new forms; the environment, the planet, is around us and is reminding us that it may have a will of its own; even God and the nation are still very much around and are being claimed as legitimation for acts of terrorism as well as wars waged against them. The old humanist world picture is far from being decommissioned, but the relationship with its constituents - technology, environment/planet, God/nation, etc. - is radically changing. All of this is calling for a new self-understanding of humans based on more benign definitions and different relationships with these others that have always been used in order to reassure ourselves. It is gradually forcing humans to face their responsibilities.

Let's take technology, or the "machine", for example. An early modern humanist understanding of machines is full of contradictions. On the one hand, the human is defined against the mechanical or the predictable - a truly human being must be free, and, in particular, free of mechanicity (today, we're aware that machines are of course so much more than just "mechanisms"). The machinic other doesn't really guarantee this exclusionary and exclusive human self-definition or self-identity, however. The exclusion of the mechanical just leads to a displacement or repression and produces a kind of anxiety (in fact, it reproduces the mechanical both as desire and threat), namely an anxiety (but also maybe a desire) of becoming interchangeable with a machine. It's one of the greatest fears of humans: how to make sure you're human and not a machine. This anxiety can only be contained if you keep on expelling everything mechanic from you and instead project it onto something else. But that's only one part of the story: the anxiety is also shot through with desire - a desire to find out what it's like to be a machine (it's one of science fiction's major tropes). If you look at the history of our relationship with machines (and technology more generally) there's also an increasing reliance on (and involvement with) machines. The history of capitalism would be unthinkable without mechanization. So, on the one hand, we try to radically differentiate ourselves from machines, on the other hand, we're constantly relying more and more on machines, aligning our lives ever more closely with them. And so this fear of becoming machine, of being "other", comes back to haunt us, troubling our "selfsameness". And, today, technology has reached a stage of development where machines actually seem livelier than us, as Donna Haraway provocatively put it, in her "Cyborg Manifesto" (1985). Machines are about to develop a life of their own, which is a big challenge for a humanistically defined human of course; and this is what may be "posthumanist" about our times. Posthumanist thinking is a deliberate toying with crossing this (largely "imaginary") boundary between human and machine. Haraway uses the cyborg as a starting point to think about new ways of imagining the relationship between humans and machines, but, importantly, not in a techno-utopian way, in the sense of let's all become superhuman cyborgs; she uses the figure of the cyborg strategically to problematize the idea of a radical difference between humans and machines. It is worth dwelling on the question: what if there is no radical difference? Time, of course, hasn't stood still since Haraway wrote her manifesto for cyborgs. Both technological development and thinking about technology have accelerated, but Haraway's was a moment that opened up a whole new space for thinking; the cyborg constituted a new idea of materialism where mechanic and living, organic and inorganic get mixed up and produce new forms of materialist (and ecological) relationships with the world.

However, there have also been powerful new idealisms around new technologies. That's where I'd locate the whole transhumanist movement and all those people who try to flip our inherent fear of technology into a kind of enthusiasm or techno-utopia, so that we embrace technological development as a means of turning humans into enhanced beings or into some kind of gods who enjoy immortality. Usually these idealisms (following a Christian and Cartesian trajectory of a strict separation between mind and body) are directly connected to desires of disembodiment; they are thus directed against our biological, material, animal or "natural" bodies. That's not the kind of posthumanism that Haraway had in mind (even though she doesn't herself use the term). As opposed to the idealist transhumanisms there is a thoroughly (new) materialist stance of becoming posthuman that I'd call "critical posthumanism". This variety of posthumanism is "critical" because it doesn't automatically (mechanically?) start with the assumption that our future lies in becoming a technological new species that hopes to overcome its embodiment.

In Posthumanism: a Critical Introduction (2013; first published in German in 2009), I tracked some of the developments since Haraway by differentiating between several versions of posthumanism. A critical posthumanism differs both from techno-utopian transhumanism and from techno-dystopian strands associated with figures of the posthuman like the iconic Arnold Schwarzenegger as "Terminator" taking off his human skin and revealing a (mechanical) steel interior. This is precisely the kind of cyborg that Haraway argued against. Instead, what she had in mind, were more (new) feminist versions of combinations of technology and humanity operating at a much more mundane (materialist and political) level. For Haraway, the cyborg could be a figure that liberates us from existing prejudice and stereotypes (based on gender, race, or, indeed, species). There is an important critical potential in letting go of traditional (essentialist) notions of what it means to be human. Technology is maybe just the inducement for this "de-essentialising", however; this doesn't mean that it's an end in itself, even if it's technological development that might have pushed us towards the need for a radical rethink of what it means to be human. This maybe 
shouldn't necessarily make us assume that technology has a dynamic of its own or is the only option (cf. Callus \& Herbrechter, 2007). There is a posthumanism that doesn't only look forward to some kind of techno-utopian developments; there's also a posthumanism that throws us back to our beginnings. How did we become to think of us as humans in the first place? I'm working on a project at the moment that my collaborator Ivan Callus and I are calling "Before Humanity" which looks at this whole story about us, the only surviving human species maybe having replaced or even killed off other humans in order to become who we are, which among many other implications has an important ecological aspect. Maybe it was climate change in the first place that made homo sapiens survive, not the Neanderthals or homo erectus. And now that we're at a stage again where we're experiencing a period of (maybe even catastrophic) climate change and where we're facing extinction ourselves all this is coming back to haunt us. It's thus not a coincidence that all this posthumanist questioning happens at a moment when the impossibility of defining "us" against nonhuman "others" becomes more and more obvious. At the moment, the emphasis is very much on inclusion rather than exclusion of nonhuman others and on not defining society against anything, because we'll need everybody: we need the planet, we need the environment, we need machines, we need animals, in order to find a way out of the mess that humans have created. The ethical, ecological, political and even the aesthetic and pedagogical responsibilities that arise from these questions is what a critical posthumanism needs to tackle. Technology, of course, but the question concerning technology, in the way Heidegger formulated it, actually opens up towards much wider questions about where a possible future may lie.

As far as the pedagogical dimension of technology and becoming human is concerned, there's always been an educational aspect to posthumanism but it has long remained implied. Not many people have been openly thinking about the educational implications of postanthropocentrism (which go far beyond environmentalist and postcolonial concerns). If you're opening up and undoing the subjectivity that humanism has been relying on - for the sake of convenience, let's call that the "liberal humanist" self, namely the idea that humans share some kind of human nature, which allows them to make more or less free decisions, which leads to the idea of a moral human being that should recognize the innate humanity of other human beings, and should therefore take the right decision and show solidarity with other humans and so on - if this sort of humanist notion of a subject is in deep trouble, the question arises what to replace it with. And that, of course, goes to the heart of education, because as well as being (biologically) human, humanism tells us that we all have to learn to be (good) humans. Now, if the human disintegrates humanism basically loses its "addressee".
People have been looking for a "human nature" that might call for humanist cultivation for a long time and haven't found it (except for a DNA sequence that we mostly share with other animals and beings). The search for a human nature meaningful enough to legitimate humanism is, most probably, a dead end. How to train humans to develop a self-understanding not based on an idea of humanity that is exclusive or exceptional, that is the great challenge for posthumanist education, because most curricula are still very much about "centring" the human - the human is always at the centre of education and how could it not be? Humans are running the world and therefore they need to be brought up in a way that gets them into the position where they can continue running this world, in a way that prolongs and legitimates their supreme rule, as long as they do so in a "humane" way. If you wanted to scratch at that consensus, you'd have to challenge what most education is about, namely (re)producing little humans. From a posthumanist view, then, you'd have to start very early, in fact you'd have to start from scratch (and given that it's still humans who're doing the scratching, even before that). You'd have to rethink the whole process of hominization that education is supposed to guide, refine and perpetuate. That involves really everything; in fact, it resembles a very ambitious programme of "unlearning to be human", in the first place. Looking at new relationships between humans and their environment, you'd have to start in primary school, or even earlier. The whole socialization process needs to change in order to include all those others that are normally excluded; instead it would promote a being-with environments, plants, animals, bacteria, minerals, objects, machines... and also humans. These are the metaphysical, ontological, ethical and political stakes if we want to develop a new, a better and more ecological relationship with our planet (as an example of how to begin tackling some of these points let me refer you to Helena Pedersen's work on animals in schools).

Now to return to the role of technology that most posthumanisms have embraced as the main driving force of change and the suggested idea of a certain "end" (singular!?) this might put to (a certain idea of!?) education: the critical posthumanism I've been advocating will see this understanding of technology and education as at once too deterministic and not radical enough. However, the impression that critical posthumanism might be technophobic would be a serious misunderstanding. There have been, undeniably, profound changes to educational practice because of technological developments, both in the past as well as, and maybe to an unprecedented extent, in the present. However, the question of what role technology actually plays, or is supposed to play, in and for education is far from simple. All too often, and especially in educational debates, we hang on to a basically utilitarian notion of technology in the sense that we use technology as a tool to change something in education, especially at a "methodological" 
level, like finding new, better, or more "effective" ways of getting through to youngsters (i.e. our prime human educational subjects). You often hear that the new generation is more techno-savvy than their teachers (which is supposed to mean: they've got the intuitive technological "skills" but don't know how to bring them to good - humanist - use). So teachers need to learn how to use the very same technology in order to "get through" to them and thus guarantee the continued address function of humanist education.

This attitude is based on a thoroughly utilitarian notion of technology, which is of course, problematic. The idea that technology is basically a tool, an extension, or a prosthesis of or for education is being thoroughly challenged by posthumanism (and Heidegger and a number of philosophies of technology before and since). Let me pick out two examples: following Derrida, who in his Of Grammatology extends the notion of writing to the realm of "nature" and biology and thus discovers a certain "technicity" at work in the very idea of "life", his student, Bernard Stiegler, further develops and complicates the temporality of this notion of "originary technicity". Actually, at no stage in the process of hominization can you reach a point where you have, on the one side, the human, and, on the other side, the technical. These two co-evolve together and continue to do so, and this leads to profound changes in the understanding of our relationship with technology, especially at a time when we have "smart" (digital) technologies that do a lot of "autonomous" things like communicating amongst themselves without any human intervention. But if technology "made" us human, so to speak, technology was there before us and might in fact survive us - this is what the phrase "life writing" might actually mean: technesis (cf. Hansen, 2000).

Imagining the "end of education" is of course a thoroughly human, if not humanist, obsession, both in the sense of end as finality and end as finitude. To what end education? Following the ambiguous humanist logic of the machine this "end" - namely that human survival depends on education - is increasingly given over to technology. In fact, machine-learning evokes both unease and admiration. On the one hand, extending the idea of teaching and learning to intelligent machines is the logical next step (including humans being, increasingly, taught by machines). But what if the machines "take over"? So, paradoxically, in a humanist sense, the end of education may also be its end. Education may be committing suicide. Neil Selwyn's provocative question: Is Technology Good for Education? (2016), unfortunately, is missing the point from a posthumanist perspective. One has to start with the assumption that education is inextricably technological, or, in other words, education is (a) technology.

For a critical posthumanism - looking forward and back at the same time - there's an entirely other "end-ofeducation" scenario to consider. Apart from (re- )producing an ontological and ethical outlook on the world based on human exceptionalism, humanism is also relying on certain fundamental (educational) "techniques" (indeed, humanism is also "technical", in the sense of "anthropo-technical"). Following Peter Sloterdijk, for example, one can understand humanism as a very specific historical chapter within the history of media-technology. Humanism is that time when national communities of people cherish the art (or media-technology) of writing letters to themselves. That's where the idea of literacy comes from. In a time when people don't write letters anymore - not just in the sense that they don't stick paper into an envelope (emails, text messages or tweets are no longer about the "art of writing" as such, even if they still involve literacy, of course) - you have completely new attitudes towards and forms of communication (i.e. new or social media) with new forms of sociality. These do not only add something to existing communities (or ways of being-with), they completely change human (and nonhuman) lives in the sense that new socialities are created based on, for example, distributed cognitive environments where not only humans do the thinking. An increasing amount of thinking is being done by machines for us and that opens up incredible possibilities. A truly posthumanist education would have to engage with this new situation and would thus no longer (at least not exclusively) be about the personal development of humans channelled by literacies. The very term "literacy" may no longer be appropriate; it still implies "letteredness" (a somewhat different case would be "numeracy", which seems to have a bright future ahead but isn't without its own humanist baggage). More appropriate might be the term "mediacy" to indicate a being-with, not only "using", but to a certain extent also being used by media, which of course doesn't just involve language (our most important medium?), but all these other more technological media that developed over time, with and through whom humans evolved and continue to do so (and nonhumans have media, too, of course; basically anything can function as a "medium" in this sense).

In summary, then, "posthumanism and the ends of education", in my view, contains a number of "postanthropological" questions that are far from technoutopian or -dystopian, but instead involve an entirely new understanding of the relationship between education, technology and the human. 
${ }^{1}$ This text is based on a radio podcast of an interview with Will Brehm, founder of FreshEd, a site designed to expand the reach of educational research; available at: http://www.freshedpodcast.com/stefanherbrechter/

\section{References}

Bradley, A. (2011). Originary technicity: The theory of technology from Marx to Derrida. Houndmills: Palgrave Macmillan. Callus, I. \& Herbrechter, S. (2007). Critical posthumanism or, the inventio of a posthumanism without technology. Subject Matters, 3(2)/4(1), 15-29.

Derrida, J. (1976). Of Grammatology. Baltimore, MD: Johns Hopkins University Press.

Hansen, M. B. N. (2000). Embodying technesis: Technology beyond writing. Ann Arbor, MI: University of Michigan Press. Heidegger, M. (1977). The Question Concerning Technology and Other Essays. New York, NY: Harper \& Row.

Herbrechter, S. (2013). Posthumanism: A critical analysis. London: Bloomsbury.

Pedersen, H. (2010). Animals in schools: Processes and strategies in human-animal education. West Lafayette, IN: Purdue University Press.

Rutsky, R. L. (1999). High technē: Art and technology from the machine aesthetic to the posthuman. Minneapolis, MN: University of Minnesota Press.

Selwyn, N. (2016). Is Technology Good for Education? Cambridge: Polity Press.

Sloterdijk, P. (2009). Rules for the human zoo: a response to the letter on humanism. Environment and Planning D: Society and Space, 27, 12-28.

Stiegler, B. (1998). Technics and time 1: The fault of epimetheus. Stanford, CA: Stanford University Press.

\section{Recommended Citation}

Herbrechter, S. (2018). Posthumanism and the ends of education. On Education. Journal for Research and Debate, 1(2). https://doi.org/10.17899/on_ed.2018.2.2

About the Author

Stefan Herbrechter is a research fellow at Coventry University and Privatdozent at Heidelberg University. Until 2014, he was Reader in Cultural Theory and Director of Postgraduate Studies (Media) at Coventry University. He is the author of Posthumanism: A Critical Analysis (Bloomsbury), as well as series editor of Critical Posthumanisms (Brill) and director of the Critical Posthumanism Network. 